This is an author produced version of a paper published in Ecological Engineering.

This paper has been peer-reviewed but may not include the final publisher proof-corrections or pagination.

Citation for the published paper:

Mårtensson, Linda- Maria; Wuolo, Annika; Fransson, Ann-Mari; Emilsson, Tobias. (2014) Plant performance in living wall systems in the Scandinavian climate. Ecological Engineering. Volume: 71, pp 610-614.

http://dx.doi.org/10.1016/j.ecoleng.2014.07.027.

Access to the published version may require journal subscription.

Published with permission from: Elsevier.

Standard set statement from the publisher:

(C) 2014, Elsevier. Licensed under the Creative Commons Attribution-NonCommercial-

NoDerivatives 4.0

Epsilon Open Archive http://epsilon.slu.se 


\title{
Title: Plant Performance in Living Wall Systems in the Scandinavian Climate
}

\author{
Authors \\ Mårtensson, L-M.*, Wuolo, A., Fransson, A-M. and Emilsson, T.
}

Affiliation of authors

Department of Landscape Architecture, Planning and Management, Swedish University of Agricultural Science, P.O. Box 58, S-230 53 Alnarp, Sweden.

E-mail addresses of authors

Linda.Maria.Martensson@slu.se

Tobias.Emilsson@slu.se

Ann-Mari.Fransson@slu.se

*Corresponding author

E-mail address: Linda.Maria.Martensson@slu.se

Tel.:+46 40415109 
Manuscript - Plant Performance in Living Wall Systems in the Scandinavian Climate

\section{Abstract}

Vertical greening has attracted increasing interest during recent years as a way of maintaining areas of vegetation despite increased urban densification. Living wall systems are a novel form of vertical greening in the Scandinavian climate and there is a lack of scientific knowledge on their functioning. We have performed a full-scale field experiment in an industrial area in Malmö, south-western Sweden, to compare the qualityquality and coverage of 16 plant species in two systems used for vertical greening. We hypothesized and found that: (1) living wall systems with perennial plants are feasible in the Scandinavian climate, (2) the qualityquality of plants was better and (2) the area covered was greater in the Rockwool system than in the pumice-filled pocket system. Individual plant species responded differently in the two systems. For example, Antennaria dioica seemed to perform well - in terms of qualityvisual quality - in the Rockwool system, but this was not reflected in the area covered. Achillea millefolia, on the other hand, showed better performance in the pumice-filled pocket system in terms of qualityquality, but this was not reflected in the area covered by the plants. Other species, such as Armeria maritima, did not perform better in either system in terms of qualityquality, but the area covered was higher in the Rockwool system. Overall, we conclude that A. millefolium, A. dioica, A. maritima, Bergenia cordifolia, Dianthus deltoides, Iberis sempervirens, Molinia caerulea, Nepeta faassenii, Pilosella aurantiaca, Salvia nemorosa and Sesleria heuffleriana are suitable for living wall systems in the Scandinavian climate. 


\section{Introduction}

The concept of green façades is not new (Koehler 2008), but their reintroduction may offer benefits in the current urban design, which is increasingly focused on urban densification. The benefits of vertical greening include noise abatement (Van Renterghem et al. 2013), filtering of airborne dust and pollutants (Ottele et al. 2010, Sternberg et al. 2010), and reduction of temperature close to the area of vertical greening (Onishi et al. 2010, Wong et al. 2010, Perini et al. 2011a). The thermal aspects of vertical greening are, however, still under debate (Hunter et al 2014). One particular type of green façade is living wall systems, which are vertical greening systems where plants are grown without the need for contact with the ground (Koehler 2008, Francis and Lorimer 2011, Perini et al. 2011b).

Living wall systems can be seen as an alternative way of introducing urban greening in dense urban areas in the same way as e.g. green roofs, which have shown to support a high arthropod diversity (Rumble and Gange 2013, Madre et al 2013). Like plants on green roofs (Emilsson and Rolf 2005, Emilsson 2008), plants in living wall systems must be able to cope with extreme conditions, such as high irradiation, considerable differences in temperature and possible water shortage.

The main aim of this study was to determine whether it is possible to grow perennial plants in living wall systems in the Scandinavian climate and we hypothesized that perennial plants could survive in, and would be a viable option for, living wall systems in the Scandinavian climate. 


\section{Materials and methods}

\subsection{Location of the study}

A full-scale field experiment was carried out in an industrial area in Malmö, SW Sweden (GPS WGS 84 decimal lat. N 55.6108, long. E 12.9896). The living wall systems were installed on the masonry wall of a building completed in 1937, facing a southern direction of $172^{\circ}$, approximately 8 metres above ground, to ensure full sun and wind exposure. The site is located in a region with a humid continental climate (Peel et al. 2007), with a local mean annual temperature of $8.7^{\circ} \mathrm{C}$ (in both 2012 and 2013), maximum temperature of $30.6^{\circ} \mathrm{C}(19$ Aug 2012) and $29.3^{\circ} \mathrm{C}$ (28 Jul 2013), minimum temperature of $-14.6^{\circ} \mathrm{C}$ (4 Feb 2012) and $15.8^{\circ} \mathrm{C}$ (25 Jan 2013) (SMHI 2014). The local mean annual precipitation was $574 \mathrm{~mm}$ in 2012 and $596 \mathrm{~mm}$ in 2013.

\subsection{The living wall systems}

Two living wall systems were investigated: a Rockwool panel system (RS) and a pumicefilled pocket system (PPS). The RS consisted of 12 prefabricated panels (Vertigreen ${ }^{\mathrm{TM}}$, Zinco GmbH) measuring 70 x 50 x 7 cm. The panels contained sheets of Rockwool, and had a plastic cover with predrilled planting holes with a layer of felt at the back for water transport. Each module was designed to have 45 planting holes, 9 large and 36 small. The distance between the large holes was 11.5 and $8.5 \mathrm{~cm}$, the small holes were placed at a distance of $2.5 \mathrm{~cm}$ from the large holes. All the large holes were planted, but only two small holes in each section, i.e. six small holes in each module. Cylindrical holes with diameters of 75 and $30 \mathrm{~mm}$ were drilled in the Rockwool, to a depth of approximately $4 \mathrm{~cm}$. A single plant was planted in each drilled hole. The plants were distributed so as to ensure that all species were present at all positions in both systems; i.e. the middle, top, bottom and sides. 
The PPS consisted of 10 on-site constructed felt pocket modules, which were constructed from a capillary mat (Klaver $300 \mathrm{~g} / \mathrm{m}^{2}$ ) and a waterproofed plywood board. Each module measured $60 \times 60 \mathrm{~cm}$, and contained 9 pockets, each with a volume of approximately 1500 $\mathrm{cm}^{3}$. Each pocket was filled with pumice and compost (10 vol.\%), and either one or two plant species was planted in each pocket to replicate the plant distribution in the RS.

\subsection{Planting}

One individual of the following was planted in the RS (12 replicates) and at the corresponding position in the PPS (10 replicates): Achillea millefolia (Ami), Antennaria dioica (Adi), Armeria maritima (Ama), Aubretia x cultorum (Acu), Bergenia cordifolia (Bco), Carex morrowii (Cmo), Dianthus deltoides (Dde), Fragaria vesca (Fve), Iberis sempervirens (Ise), Iris sibirica (Isi), Molinia caerulea (Mca), Nepeta faassenii (Nfa), Pilosella aurantiaca (Pau), Salvia nemorosa (Sne), Sesleria heuffleriana (She), and Stachys byzantina (Sby). The soil was washed off the plant roots prior to planting in the RS in order to achieve good contact with the substrate. The substrate in the PPS contained compost and the substrate on the plants at deliver was only shaken off before planting. The growth substrate in both systems was generously irrigated before and after planting. Planting was carried out on $15^{\text {th }}$ June 2012.

\subsection{Irrigation and fertilization}

During the rest of 2012, both systems were irrigated for 10 minutes, three times a day; in the evening, night and morning. From the start of 2013, the PPS was irrigated for 15 minutes twice a day; in the evening and night, and the RS for one hour every other day. The total water storage of the RS was higher than in the PPS, which also have a higher permeability. Thus, the RS could be irrigated with larger volumes at more sparse intervals without risk of 
increasing runoff. In 2012, approximately $20 \mathrm{ml}$ liquid fertilizer (Blomstra, Cederroth Sverige $\mathrm{AB}$ ) was added to each module in both systems, twice during the growing season (from June to September): once, one week after planting and then again after another month. This fertilization was a low establishment dose, one fourth of the recommended, aimed to secure a well-developed rooting system. However, this mode of distribution caused a decreasing growth from the top to the bottom of the systems and fertilization was not distributed hydroponically the following year. Approximately $16 \mathrm{ml}$ liquid fertilizer was added to each module in both systems each month during the growing season of 2013, distributed as $4 \mathrm{ml}$ portions in 4 places across the modules. This is equivalent to a full nutrient fertilisation, however, in the low range.

\subsection{Data collection and statistical analysis}

Plant visual quality was assessed on a scale from $0-4$, as modified from Zollinger et al. (2006), in June and August 2012 and in April, June and August in 2013. Gradations were: 0 $=100 \%, 1=>50 \%, 2=<25 \%, 3=<10 \%$, and $4=0 \%$ dead or wilted leaves. The area covered by vegetation was measured (vertical x horizontal direction) in June 2012, August 2012 and June 2013. The Wilcoxon signed rank test (IBM SPSS Statistics 20) was used to test the difference between plant visual qualities in the two systems.

\section{Results}

The overall quality of the plants differed between the two living wall systems investigated in June 2012, April 2013 and August 2013 (Tab. 1). The overall visual quality was better in the RS than in the PPS in both June 2012 and April 2013. However, the visual quality was better in the PPS in August 2013. The overall covered area was greater in the PPS than in the RS on all occasions (Tab. 2). 
The individual visual quality of the 16 plant species used in the experiment (Tab. 3), 5 species: Bco, Cmo, Fve, Ise and Nfa had a better visual quality in the RS than in the PPS in June 2012, just after planting. Ami and Dde showed the opposite behaviour, i.e. better quality, in the PPS in June 2012. Mca and Sby showed a better quality in the RS than in the PPS in August 2012, towards the end of the growing season. Bco, Cmo, Dde, Nfa, Pau and She had a better quality in the PPS in August 2012.

Adi and Sby had a better quality in the RS than in the PPS in April 2013, after the winter. Adi, Cmo and Fve had a better quality in the RS than in the PPS in June. Ami, Bco, Dde, Nfa and She had a better quality in the PPS than in the RS in June 2013. Fve had a better quality in the RS than in the PPS in August 2013. Ami and Nfa had a better quality in the PPS than in the RS in August 2013. No significant difference in quality was found for Ama, Acu, Isi or Sne in the two systems investigated.

In June 2012, the area covered by Acu, Isi, Mca, Nfa, Sne, She and Sby was significantly larger in the PPS than in the RS. Acu, Bco, Cmo, Dde, Isi, Sne and Sby covered a larger area in the PPS at the end of the growing season (August 2012). Ama showed the opposite behaviour, and covered a significantly larger area in the RS in August 2012. In June 2013, no significant differences were found between the systems regarding the area covered. Ami, Adi, Fve, Ise and Pau did not show any significant difference in coverage between the two systems at any time (Tab. 4).

\section{Discussion}

We have shown that perennial plants can survive in living wall systems in the climate of southern Sweden. The experiment was performed on a south-facing wall, with a highly variable climate including cold winter and spring, and hot dry summers. Most species 
performed well - in terms of visual quality or large cover area - in both systems, but Acu, Cmo, Fve, Isi and Sby performed poorly in this experiment. However, the partially evergreen character of Cmo, the flowering of Isi and Ise and the fruiting of Fve may make them desirable among perennial plants for green walls, despite their poor performance. These examples illustrate the difficulty of using only quality and coverage as parameters to describe plant performance.

The better quality in the RS during the establishment period and the first growing season, as well as the early spring in 2013, may be explained by better contact between the growth substrate and the roots, and a higher water holding capacity, in the Rockwool than in the pumice. Air-filled space in the mixture of pumice and compost may have reduced the direct contact between the roots and the water-supplying substrate (Grossnickle 2005). Later in the seasons the quality of the plants was similar in the systems.

The overall pattern of better quality in the RS after planting (June 2012), but in the PPS later in the season (August 2012), was seen in Bco and Nfa. Bco, with its thick, leathery leaves (Mossberg and Stenberg 2003, Plant Database Ltd. 2013) is expected to perform well in any living wall system, and this was confirmed by its good quality and high cover. Nfa is adapted to neutral to alkaline soils, and has moderate drought adaption (Plant Database Ltd. 2013), and is therefore expected to thrive in living wall systems. Both species also provided generous amounts of flowers during long periods of the growing season. Ami has a wide ecological niche in terms of water availability (Ellenberg 1974) and the roots of Ami are known to stretch deep down in a soil with low availability of water and nutrients (O’Dell and Claassen, 2006). However, they are restricted from doing so in the RS, which could have a negative effect on the quality. 
Ama overall successful response in both systems is in agreement with its natural occurrence in dry, sandy habitats (Mossberg and Stenberg 2003), which are well-drained and nutrient poor (Mårtensson and Olsson 2010), and where competition between plants is low. Ama is often found in stressed environments in costal urban areas, such as road verges, and is often used on green roofs (Nagase and Dunnett 2013). However, Ama did not cover large areas of the growth system, but contributed through a generous flowering during a long season. Surprisingly, Isi showed a good quality despite this natural habitat preference, but the coverage is largely provided by the length of the leaves, and does not contribute to the coverage of the growth system. In the Scandinavian landscape, Isi occurs in remnant domestic gardens, roadsides, roadside ditches and wet meadows (Mossberg and Stenberg 2003), which demonstrates its preference for moderately moist and nutrient-rich habitats. Sne is found on moderately moist and nutrient-rich soils (Mossberg and Stenberg 2003), but is successful in living wall systems. Sne was equally vital in both systems, but covered a larger area in the PPS. However, the species showed general good quality, large coverage and flowers during long periods of the growing season, and can thus be regarded as highly suitable for living wall systems.

\section{Conclusions}

The most suitable plant species for living wall systems in our experiment were Achillea millefolia, Bergenia cordifolia, Dianthus deltoides, Molinia caerulea, Nepeta faassenii, Salvia nemorosa and Sesleria heuffleriana. This conclusion is based primarily on the visually assessed quality of the plants and secondarily on the area covered. However, flowering plants with low coverage but good quality, such as Antennaria dioica, Armeria 
Manuscript - Plant Performance in Living Wall Systems in the Scandinavian Climate

maritima, Iberis sempervirens and Pilosella aurantiaca are also suitable for living wall systems when accompanied by species with a larger coverage.

Further research on plant choice, irrigation and fertilization is essential for the development and design of appropriate living wall systems in the Scandinavian climate and regions with similar conditions. Since living wall systems are being increasingly used in the urban landscape, it is of vital importance to use resource-efficient constructions in which both the technical and plant design are sustainable. If living walls are designed with these prerequisites, they may be considered a form of ecological engineering (Mitsch 2012).

\section{Acknowledgements}

The Swedish Research Council FORMAS is acknowledged for funding this research project. PEAB is acknowledged for allowing us to use the wall of the industrial building in Malmö, Sweden, and for assistance in the installation and management of the systems.

\section{References}

Ellenberg, H., 1974. Indicator values of vascular plants in Central Europe. Scripta Geobot. 9:1-97.

Emilsson, T., 2008. Vegetation development on extensive vegetated green roofs: Influence of substrate composition, establishment method and species mix. Ecol. Eng. 33:265-277. Emilsson, T., Rolf, K., 2005. Comparison of establishment methods for extensive green roofs in southern Sweden. Urban For. Urban Green. 3:103-111.

Francis, R. A., Lorimer, J., 2011. Urban reconciliation ecology: The potential of living roofs and walls. J. Environ. Manag. 92:1429-1437.

Grossnickle, S. C., 2005. Importance of root growth in overcoming planting stress. New For. 30:273-294. 
Manuscript - Plant Performance in Living Wall Systems in the Scandinavian Climate

Hunter, A. M., Williams, N.S.G., Rayner, J.P., Aye, L., Hes, D, Livesley, S.J., 2014. Quantifying the thermal performance of green facades: A critical review. Ecol. Eng. 63:102113.

Koehler, M., 2008, Green facades-a view back and some visions. Urban Ecosys. 11:423436.

Madre, F., Vergnes, A., Machon, N., Clergeau, P., 2013. A comparison of 3 types of green roofs as habitats for arthropods. Ecol .Eng. 57:109-117.

Martensson, L.-M., Olsson, P. A., 2010. Soil chemistry of local vegetation gradients in sandy calcareous grasslands. Plant Ecol. 206:127-138.

Mitsch, W.J., 2012. What is ecological engineering? Col. Eng. 45:5-12.

Mossberg, B., Stenberg, L., 2003. Den nya nordiska floran. Wahlström \& Widstrand, Stockholm.

Nagase, A., Dunnett, N., 2013. Establishment of an annual meadow on extensive green roofs in the UK. Landsc. Urban Plan. 112:50-62.

O’Dell, R. E., Claassen, V.P., 2006. Vertical distribution of organic amendment influences the rooting depth of revegetation species on barren, subgrade serpentine substrate. Plant Soil 285:19-29.

Onishi, A., Cao, X., Ito, T., Shi, F., Imura, H., 2010. Evaluating the potential for urban heatisland mitigation by greening parking lots. Urban For. Urban Green. 9:323-332.

Ottele, M., Bohemen, H. D. v., Fraaij, A. L. A., 2010. Quantifying the deposition of particulate matter on climber vegetation on living walls. Ecol. Eng. 36:154-162.

Peel, M. C., Finlayson, B. L., McMahon, T. A., 2007. Updated world map of the KöppenGeiger climate classification. Hydrol. Earth Syst. Sci. 11:1633-1644. 
Perini, K., Ottele, M., Fraaij, A. L. A., Haas, E. M., Raiteri, R., 2011a. Vertical greening systems and the effect on air flow and temperature on the building envelope. Build. Environ. 46:2287-2294.

Perini, K., Ottele, M., Haas, E. M., Raiteri, R., 2011b. Greening the building envelope, facade greening and living wall systems. Open J Ecol. 1:1-8.

Plant Database Ltd. 2013. http://www.plantdatabase.co.uk/ [2013-12-02]

Rumble, H., Gange, A.C., 2013. Soil arthropod community dynamics in extensive green roofs. Ecol. Eng. 57:197-204.

Sternberg, T., Viles, H., Cathersides, A., Edwards, M., 2010. Dust particulate absorption by ivy (Hedera helix L.) on historic walls in urban environments. Sci. Total Environ. 409:162168.

Van Renterghem, T., Hornikx, M., Forssen, J., Botteldooren, D., 2013. The potential of building envelope greening to achieve quietness. Build. Environ. 61:34-44.

Wong, N. H., Tan, A. Y. K., Chen, Y., Sekar, K., Tan, P. Y., Chan, D., Chiang, K., Wong, N. C., 2010. Thermal evaluation of vertical greenery systems for building walls. Build. Environ. 45:663-672.

Zollinger, N. Kjelgren, R., Cerny-Koenig, T., Kopp, K., Koenig, R., 2006. Drought responses of six ornamental herbaceous perennials. Sci. Hortic. 109:267-274.

SMHI (2014) Swedish Meteorological and Hydrological Institute, www.smhi.se, retrieved 2014-04-28. 
Table 1 Overall plant visual quality (based on gradations 0-4) in the pumice system (PPS) and the Rockwool system (RS) presented as means, standard deviations and number of individuals. Results from the Wilcoxon signed rank test are presented as $Z$ and p-values, where $\mathrm{p}<0.05$ indicates significant difference between the two systems.

\begin{tabular}{lccc} 
& \multicolumn{2}{c}{ Plant quality } & Wilcoxon signed rank test \\
\cline { 2 - 4 } Time & PPS & RS & \\
\hline June 2012 & $2.23(1.174) \mathrm{N}=158$ & $2.70(1.039) \mathrm{N}=192$ & $Z=-4.233 ; \mathrm{p}=0.000$ \\
August 2012 & $2.79(1.505) \mathrm{N}=144$ & $2.76(0.877) \mathrm{N}=192$ & $Z=-0.043 ; \mathrm{p}=0.966$ \\
April 2013 & $0.85(1.012) \mathrm{N}=149$ & $1.09(1.047) \mathrm{N}=192$ & $Z=-2.627 ; \mathrm{p}=0.009$ \\
June 2013 & $2.43(1.635) \mathrm{N}=160$ & $2.40(1.262) \mathrm{N}=189$ & $Z=-1.248 ; \mathrm{p}=0.212$ \\
August 2013 & $1.93(1.378) \mathrm{N}=156$ & $1.67(1.004) \mathrm{N}=192$ & $Z=-2.631 ; \mathrm{p}=0.009$ \\
\hline
\end{tabular}


Table 2 The total area covered $\left(\mathrm{cm}^{2}\right)$ by the plants in the pumice system (PPS) and the Rockwool system (RS) presented as means, standard deviations and number of individuals are given. Results from the Wilcoxon signed rank test are presented as $Z$ and pvalues, where $\mathrm{p}<0.05$ indicates significant difference between the two systems.

\begin{tabular}{lccc} 
& \multicolumn{2}{c}{ Area covered $\left.\mathbf{( c m}^{2}\right)$} & Wilcoxon signed rank test \\
\cline { 2 - 4 } Time & PPS & RS & \\
\hline June 2012 & $658(653) \mathrm{N}=103$ & $342(286) \mathrm{N}=139$ & $Z=-5.659 ; \mathrm{p}=0.000$ \\
August 2012 & $687(567) \mathrm{N}=116$ & $521(528) \mathrm{N}=155$ & $Z=-4.034 ; \mathrm{p}=0.000$ \\
June 2013 & $538(469) \mathrm{N}=71$ & $313(309) \mathrm{N}=111$ & $Z=-2.919 ; \mathrm{p}=0.004$ \\
\hline
\end{tabular}


Table 3 Visual quality of leaves of individual plant species presented as means, standard errors and number of individuals. Bold italics indicate significant differences $(\mathrm{p}<0.05)$ between the two systems; PPS = pumice-filled pocket system and RS = Rockwool panel system, and arises from Wilcoxon signed rank test.

\begin{tabular}{|c|c|c|c|c|c|c|}
\hline \multirow{2}{*}{ Species } & & \multicolumn{5}{|c|}{ Visual quality } \\
\hline & & June 2012 & August 2012 & April 2013 & June 2013 & August 2013 \\
\hline \multirow{2}{*}{ A. millefolia } & PPS & $3.3(0.21) N=10$ & $2.6(0.65) \mathrm{N}=9$ & $0.50(0.31) \mathrm{N}=10$ & $3.9(0.10) N=10$ & $3.2(0.25) N=10$ \\
\hline & RS & $2.7(0.19) N=12$ & $3.3(0.13) \mathrm{N}=12$ & $0.6(0.15) \mathrm{N}=12$ & $3.6(0.15) N=12$ & $2.0(0.12) N=12$ \\
\hline \multirow[t]{2}{*}{ A. dioica } & PPS & $2.2(0.55) \mathrm{N}=9$ & $2.7(0.67) \mathrm{N}=9$ & $0.40(0.22) N=10$ & $1.0(0.54) N=10$ & $1.7(0.56) \mathrm{N}=10$ \\
\hline & RS & $2.8(0.39) \mathrm{N}=12$ & $2.7(0.40) \mathrm{N}=12$ & $1.8(0.35) N=12$ & $2.6(0.34) N=11$ & $1.7(0.33) \mathrm{N}=12$ \\
\hline \multirow[t]{2}{*}{ A. maritima } & PPS & $2.9(0.46) \mathrm{N}=9$ & $2.2(0.70) \mathrm{N}=9$ & $2.4(0.22) \mathrm{N}=10$ & $3.7(0.15) \mathrm{N}=10$ & $3.2(0.44) \mathrm{N}=10$ \\
\hline & RS & $3.8(0.18) \mathrm{N}=12$ & $3.5(0.15) \mathrm{N}=12$ & $2.2(0.11) \mathrm{N}=12$ & $3.6(0.19) \mathrm{N}=12$ & $3.2(0.21) \mathrm{N}=12$ \\
\hline \multirow[t]{2}{*}{ A. $x$ cultorum } & PPS & $2.0(0.29) \mathrm{N}=10$ & $2.3(0.33) \mathrm{N}=9$ & $1.6(0.22) \mathrm{N}=10$ & $2.2(0.29) \mathrm{N}=10$ & $1.3(0.21) \mathrm{N}=10$ \\
\hline & RS & $1.8(0.18) \mathrm{N}=12$ & $2.5(0.15) \mathrm{N}=12$ & $1.9(0.23) \mathrm{N}=12$ & $2.0(0.21) \mathrm{N}=12$ & $1.3(0.13) \mathrm{N}=12$ \\
\hline \multirow{2}{*}{ B. cordifolia } & PPS & $3.1(0.10) N=10$ & $3.7(0.17) N=9$ & $2.0(0.31) \mathrm{N}=7$ & $3.3(0.15) N=10$ & $2.5(0.17) \mathrm{N}=10$ \\
\hline & RS & $3.8(0.13) N=12$ & $3.1(0.15) N=12$ & $2.2(0.17) \mathrm{N}=12$ & $2.8(0.21) N=12$ & 17) $\mathrm{N}=12$ \\
\hline \multirow[t]{2}{*}{ C. morrowii } & PPS & $1.5(0.22) N=10$ & $3.7(0.17) N=9$ & 42) $N=6$ & $0.70(0.15) N=10$ & 0.34) $N=7$ \\
\hline & RS & $2.0(0.17) N=12$ & $2.5(0.23) N=12$ & $\mathrm{~N}=12$ & $1.6(0.23) N=12$ & $\mathrm{~N}=12$ \\
\hline \multirow[t]{2}{*}{ D. deltoides } & PPS & $3.0(0.26) N=10$ & $4.0(0.00) N=9$ & $1.0(0.26) \mathrm{N}=10$ & $3.5(0.40) N=10$ & $2.1(0.31) \mathrm{N}=10$ \\
\hline & RS & $2.3(0.33) N=12$ & $2.8(0.13) N=12$ & $1.3(0.18) \mathrm{N}=12$ & $2.0(0.35) N=12$ & $1.5(0.20) \mathrm{N}=12$ \\
\hline \multirow[t]{2}{*}{ F. vesca } & PPS & $0.0(0.0) N=10$ & $1.1(0.59) \mathrm{N}=9$ & $0.0(0.0) \mathrm{N}=10$ & $0.40(0.40) N=10$ & $0.30(0.30) N=10$ \\
\hline & RS & $1.3(0.25) N=12$ & $0.80(0.33) \mathrm{N}=12$ & $0.40(0.19) \mathrm{N}=12$ & $2.8(0.33) N=10$ & $1.3(0.28) N=12$ \\
\hline \multirow[t]{2}{*}{ I. sempervirens } & PPS & $2.9(0.23) N=10$ & $3.7(0.33) \mathrm{N}=9$ & $(0.33) \mathrm{N}=10$ & $2.0(0.47) \mathrm{N}=10$ & $1.7(0.60) \mathrm{N}=10$ \\
\hline & RS & $3.8(0$ & $\mathrm{N}=12$ & $\mathrm{~N}=12$ & $1.5(0.31) \mathrm{N}$ & 6) $\mathrm{N}=12$ \\
\hline \multirow[t]{2}{*}{ I. sibirica } & PPS & $2.0(0.26) \mathrm{N}=10$ & .29) $\mathrm{N}=9$ & $0.20(0.13) \mathrm{N}=10$ & $2.8(0.61) \mathrm{N}=10$ & .41) $\mathrm{N}=10$ \\
\hline & RS & $2.7(0.19) \mathrm{N}=12$ & $2.3(0.28) \mathrm{N}=12$ & $0.0(0.0) \mathrm{N}=12$ & $1.3(0.57) \mathrm{N}=12$ & $0.20(0.11) \mathrm{N}=12$ \\
\hline \multirow[t]{2}{*}{ M. caerulea } & PPS & $1.6(0.52) \mathrm{N}=10$ & $0.0(0.0) N=9$ & $0.0(0.0) \mathrm{N}=10$ & $2.9(0.50) \mathrm{N}=10$ & $2.2(0.51) \mathrm{N}=10$ \\
\hline & RS & $3.0(0.33) \mathrm{N}=12$ & $2.8(0.17) N=12$ & $0.0(0.0) \mathrm{N}=12$ & $3.6(0.19) \mathrm{N}=12$ & $2.8(0.22) \mathrm{N}=12$ \\
\hline \multirow[t]{2}{*}{ N. faassenii } & PPS & $2.1(0.10) N=10$ & $3.7(0.17) N=9$ & $0.88(0.13) \mathrm{N}=8$ & $3.9(0.10) N=10$ & $2.6(0.16) N=10$ \\
\hline & RS & $2.8(0.11) N=12$ & $3.0(0.0) N=12$ & $0.83(0.11) \mathrm{N}=12$ & $2.8(0.33) N=12$ & $1.8(0.21) N=12$ \\
\hline \multirow[t]{2}{*}{ P. aurantiaca } & PPS & $2.4(0.48) \mathrm{N}=10$ & $4.0(0.0) N=9$ & $0.0(0.0) \mathrm{N}=9$ & $2.3(0.63) \mathrm{N}=10$ & $1.5(0.40) \mathrm{N}=10$ \\
\hline & RS & $2.7(0.19) \mathrm{N}=12$ & $3.2(0.17) N=12$ & $0.17(0.11) \mathrm{N}=12$ & $2.4(0.36) \mathrm{N}=12$ & $1.3(0.23) \mathrm{N}=12$ \\
\hline \multirow[t]{2}{*}{ S. nemorosa } & PPS & $2.6(0.22) \mathrm{N}=10$ & $3.1(0.11) \mathrm{N}=9$ & $0.33(0.33) \mathrm{N}=9$ & $3.5(0.40) \mathrm{N}=10$ & $2.8(0.15) \mathrm{N}=9$ \\
\hline & RS & $3.6(0.19) \mathrm{N}=12$ & $3.0(0.0) \mathrm{N}=12$ & $0.0(0.0) \mathrm{N}=12$ & $3.3(0.14) \mathrm{N}=12$ & $2.2(0.21) \mathrm{N}=12$ \\
\hline \multirow[t]{2}{*}{ S. heuffleriana } & PPS & $2.1(0.18) \mathrm{N}=10$ & $3.4(0.18) N=9$ & $1.2(0.13) \mathrm{N}=10$ & $2.1(0.10) N=10$ & $2.2(0.20) \mathrm{N}=10$ \\
\hline & RS & $2.0(0.0) \mathrm{N}=12$ & $2.8(0.11) N=12$ & $1.1(0.08) \mathrm{N}=12$ & $1.6(0.15) N=12$ & $1.6(0.15) \mathrm{N}=12$ \\
\hline \multirow[t]{2}{*}{ S. bysantina } & PPS & $2.2(0.13) \mathrm{N}=10$ & $2.0(0.24) N=9$ & $0.10(0.10) N=10$ & $0.60(0.22) \mathrm{N}=10$ & $1.2(0.51) \mathrm{N}=10$ \\
\hline & RS & $2.4(0.26) \mathrm{N}=12$ & $3.0(0.0) N=12$ & $0.58(0.15) N=12$ & $1.1(0.23) \mathrm{N}=12$ & $1.0(0.21) \mathrm{N}=12$ \\
\hline
\end{tabular}


Table 4 The area covered $\left(\mathrm{cm}^{2}\right)$ by individual plant species are presented as means, standard deviations and number of individuals. Bold italics indicate significant differences $(\mathrm{p}<0.05)$ between the two systems; PPS = pumice-filled pocket system and RS = Rockwool panel system, and arises from Wilcoxon signed rank test.

\begin{tabular}{|c|c|c|c|c|}
\hline \multirow[b]{2}{*}{ Species } & & \multicolumn{3}{|c|}{ Cover area $\left(\mathrm{cm}^{2}\right)$} \\
\hline & & June 2012 & August 2012 & June 2013 \\
\hline \multirow[t]{2}{*}{ A. millefolia } & PPS & $281(116) \mathrm{N}=8$ & $686(447) \mathrm{N}=8$ & 837 (549) N=6 \\
\hline & RS & $208(90) \mathrm{N}=10$ & 457 (107) N=10 & $457(154) \mathrm{N}=8$ \\
\hline \multirow[t]{2}{*}{ A. dioica } & PPS & $38.7(24.4) \mathrm{N}=7$ & $69.0(50.0) \mathrm{N}=9$ & $127(23.3) \mathrm{N}=2$ \\
\hline & RS & $47.9(24.8) \mathrm{N}=9$ & $80.8(38.5) \mathrm{N}=9$ & $115(92.6) \mathrm{N}=7$ \\
\hline \multirow[t]{2}{*}{ A. maritima } & PPS & $196(92.9) \mathrm{N}=8$ & $209(58.2) N=8$ & $261(123) \mathrm{N}=6$ \\
\hline & RS & $286(67.5) \mathrm{N}=10$ & $406(105) N=10$ & 159 (58.8) N=8 \\
\hline \multirow[t]{2}{*}{ A. x cultorum } & PPS & $262(62.6) N=8$ & $219(70.2) N=8$ & $334(34.0) \mathrm{N}=6$ \\
\hline & RS & $152(62.6) N=10$ & $158(64.2) N=10$ & $165(92.2) \mathrm{N}=8$ \\
\hline \multirow[t]{2}{*}{ B. cordifolia } & PPS & - & $849(196) N=8$ & $444(170) \mathrm{N}=6$ \\
\hline & RS & $355(123) \mathrm{N}=10$ & $470(166) N=10$ & $324(110) \mathrm{N}=8$ \\
\hline \multirow[t]{2}{*}{ C. morrowii } & PPS & $616(331) \mathrm{N}=8$ & $1380(629) N=8$ & 298 (393) $N=3$ \\
\hline & RS & $487(346) \mathrm{N}=10$ & $720(454) N=9$ & 591 (239) $N=7$ \\
\hline \multirow[t]{2}{*}{ D. deltoides } & PPS & $169(43.2) \mathrm{N}=8$ & $437(170) N=8$ & $873(429) \mathrm{N}=5$ \\
\hline & RS & $163(48.8) \mathrm{N}=10$ & $220(77.4) N=10$ & $183(120) \mathrm{N}=7$ \\
\hline \multirow[t]{2}{*}{ F. vesca } & PPS & - & $20(-) \mathrm{N}=1$ & - \\
\hline & RS & - & $32.7(23.2) \mathrm{N}=7$ & $30.3(21.0) \mathrm{N}=6$ \\
\hline \multirow[t]{2}{*}{ I. sempervirens } & PPS & - & $128(56.7) \mathrm{N}=8$ & $91.6(53.7) \mathrm{N}=5$ \\
\hline & RS & - & $111(27.0) \mathrm{N}=10$ & $134(91.9) \mathrm{N}=6$ \\
\hline \multirow[t]{2}{*}{ I. sibirica } & PPS & $1280(780) N=8$ & $952(426) N=8$ & $267(233) \mathrm{N}=5$ \\
\hline & RS & $406(200) N=10$ & $318(224) N=10$ & $64.5(6.36) \mathrm{N}=2$ \\
\hline \multirow[t]{2}{*}{ M. caerulea } & PPS & $593(125) N=8$ & $688(303 \mathrm{~N}=7$ & $477(274) \mathrm{N}=5$ \\
\hline & RS & $283(87.5) N=10$ & $920(894) \mathrm{N}=10$ & $472(299) \mathrm{N}=8$ \\
\hline \multirow[t]{2}{*}{$N$. faassenii } & PPS & $930(334) N=8$ & 936 (279) $N=8$ & $912(366) \mathrm{N}=6$ \\
\hline & RS & $473(241) N=10$ & $976(305) \mathrm{N}=10$ & $379(294) \mathrm{N}=8$ \\
\hline \multirow[t]{2}{*}{ P. aurantiaca } & PPS & $241(128) \mathrm{N}=8$ & $262(102) \mathrm{N}=7$ & $340(18.6) \mathrm{N}=3$ \\
\hline & RS & $226(60.1) \mathrm{N}=10$ & $316(186) \mathrm{N}=10$ & $63.7(41.8) \mathrm{N}=6$ \\
\hline \multirow[t]{2}{*}{ S. nemorosa } & PPS & $990(475) N=8$ & 997 (353) $N=7$ & $537(215) \mathrm{N}=5$ \\
\hline & RS & $388(89.3) N=10$ & $812(312) N=10$ & $398(154) \mathrm{N}=8$ \\
\hline \multirow[t]{2}{*}{ S. heuffleriana } & PPS & $2240(298) N=8$ & $1880(364) \mathrm{N}=8$ & $1320(698) \mathrm{N}=6$ \\
\hline & RS & 1050 (363) $N=10$ & $1800(373) \mathrm{N}=10$ & $967(467) \mathrm{N}=8$ \\
\hline \multirow[t]{2}{*}{ S. bysantina } & PPS & $646(234) N=8$ & $530(134) N=8$ & $83.5(84.1) \mathrm{N}=2$ \\
\hline & RS & $232(124) N=10$ & $365(99.3) N=10$ & $79.7(70.3) \mathrm{N}=6$ \\
\hline
\end{tabular}

